\title{
Sistem Management Inventory Suku Cadang (Bengkel PT. Sinar Mas)
}

\author{
Riri Ferial ${ }^{1)}$, Ihsan Lubis ${ }^{2}$, Arie Rafika Dewi, ${ }^{3)}$ \\ Program Studi Sistem Informasi. Universitas Harapan Medan. \\ Alamat Jl. HM Joni No. 70C, Medan 20217
}

\begin{abstract}
Abstrak-PT. ASM bergerak dibidang asuransi kendaraaan bermotor. saat ini pendataan barang dan penjualan yang di lakukan pada unit bengkel PT.ASM masih dikerjakan secara manual, dengan cara menulis data barang masuk dan barang keluar pada buku catatan setiap hari nya. Padahal, teknologi komputer telah digunakan untuk melakukan pendataan penjualan pada PT.ASM namun, hanya dalam bentuk file excel. Sebelum data di masukan ke komputer, maka data tersebut terlebih dahulu dituliskan pada buku secara manual dan kemudian dimasukkan ke dalam komputer. Melalui cara ini, pemilik maupun karyawan yang bekerja mungkin tidak akan menemui kesulitan yang berarti, namun, diakui tingkat kesalahan dalam penghitungan jumlah barang dan juga dalam penulisan data penjualan cukup tinggi resiko nya. dalam Penelitian ini menggunakan Metode Waterfall, metode waterfall memiliki model yang klasik yang juga sederhana dengan aliran sistem yang linier (berurutan), yang mengalir kebawah seperti air terjun. Hasil Output dari setiap tahap merupakan input bagi tahap berikutnya. Solusi yang di berikan kepada perusahaan ini ialah pengunaan aplikasi berbasis android yang dimana dalam aplikasi tersebut diharapkan dapat memudahkan karyawan dalam merekap pendataan barang masuk dan juga barang keluar yang di kerjakan setiap harinya,dalam pengunaan aplikasi ini karyawan dapat melakukan pekerjaan dimana saja dan kapan saja dengan mudah dan lebih efisien, hasil perekapan data yang dikerjakan akan dapat di unduh dalam aplikasi tersebut, sehinga karyawan tidak perlu mengulang kembali setiap bulan nya untuk menghitung data barang yang masuk dan juga barang keluar.
\end{abstract}

Kata kunci: Pendataan Barang,Laporan Barang

\section{Pendahuluan}

Komputerisasi yang sudah cangih pada zaman sekarang ini akan mempercepat dan sangat mempermudah dalam menghadapi kesulitan dalam mengambil keputusan kapan barang akan dipesan lagi[1]. Pemilik perusahaan pada PT.ASM biasanya juga sering ingin mengetahui seberapa besar nya penghasilan yang diperoleh perusahaan dalam jangka waktu yang di tetapkan oleh pemilik perusahaan tersebut, Selain itu juga akan terjadi kesulitan dalam mengetahui berapa jumlah sisa stok yang ada pada perusahaan[2].Sistem ini akan diterapkan pada PT.ASM yang bergerak pada perbaikan kendaraan roda empat atau mobil. Dalam proses perbaikan umum nya pihak bengkel akan melakukan permintaan barang pada pihak gudang terlebih dahulu, yang kemudian akan di cek oleh pihak gudang dengan melakukan validasi permintaan pada kantor, kemudian pengecekan ketersediaan barang, pembuatan surat permintaan barang, laporan barang keluar, dan juga pencataan penggunaan barang. Hal ini masih dilakukan dalam bentuk sistem manual yang pada dasarnya pasti akan memakan waktu lama untuk pengerjaannya. Sehingga penulis yang melaksanakan PKL di PT.ASM berupaya membuat sebuah sistem terdigitalisasi khusus untuk menggantikan sistem manual yang sebelum nya dilakukan dengan pencatatn di buku lalu di masukan pada file excel. Dalam penelitian ini penulis memberikan solusi pada perusahaan PT.ASM adalah melakukan upgrade pendataan yang manual mengunakan pendataan barang sparepart yang lebih memudahkan dan juga data yang lebih aman, yaitu dengan mengunakan aplikasi android yang lebih efisien dan juga pendataan barang sparepart yang lebih aman.

\section{Tinjauan Pustaka}

Basis data ialah sebuah kumpulan dari data yang di mana mereka saling berhubungan antara satu dengan yang lain[3]. Basis data atau database juga merupakan salah satu bagian komponen yang penting dalam sistem informasi, karena ia berfungsi sebagai basis penyediaan data informasi bagi sipengunanya[11], Sistem basis data adalah suatu sistem informasi yang mengintegrasikan kumpulan dari data yang saling berhubungan dengan data yang lainnya dan untuk membuatnya tersedia beberapa aplikasi yang bermacam-macam dalam suatu sistem organisasi[4]. Sistem basis data adalah suatu sistem menyusun dan mengelola record-record menggunakan komputer untuk menyimpan atau merekam serta memelihara data operasional lengkap sebuah organisasi atau perusahaan sehingga mampu menyediakan informasi yang optimal[5].

\section{Metode Penelitian}

Pada tahap ini dilakukan pengamatan mengenai permasalahan yang terjadi pada PT.ASM, berkaitan dengan proses pendataan dan persediaan pada bagian inventory, Pada Perancangan Aplikasi Sistem Inventory Berbasis Android (Studi Kasus PT.ASM, penulis merancang beberapa rancangan sebagai berikut.Use Case Diagram 
PT.ASM Berikut gambar use case diagram untuk sistem Perancangan Aplikasi Sistem Inventory Berbasis Android (Studi Kasus PT.ASM).

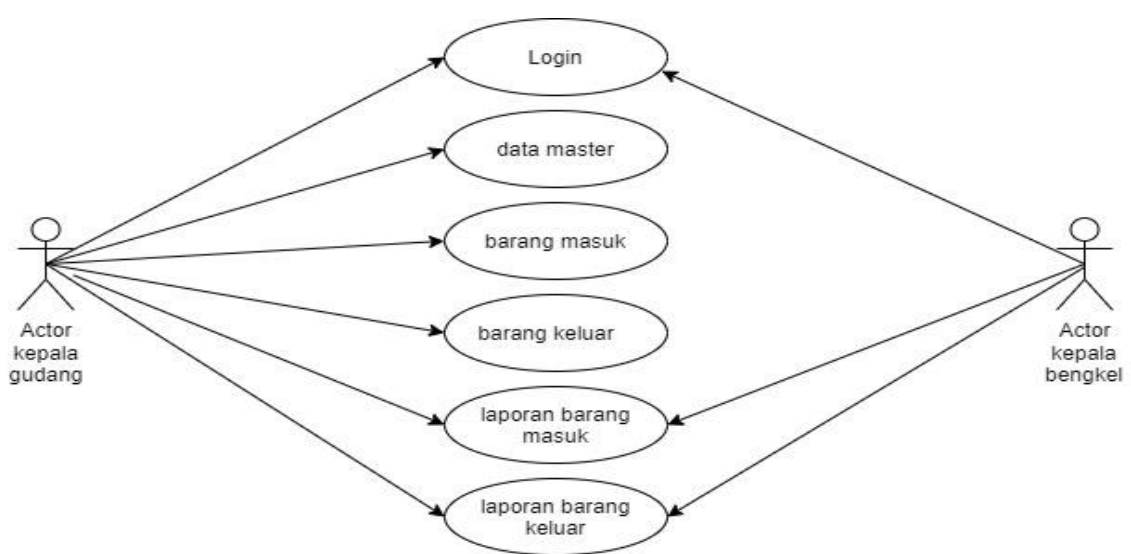

Gambar 1. Use Case Diagram Area Admin

Gambar diatas merupakan use case diagram sistem yang menjelaskan hubungan antara aktor dan sistem[6]. Use case memiliki 2 aktor dan 6 use case. Aktor terdiri dari admin 1 (kepala gudang) dan admin 2 (kepala gudang). Admin 1 akan memeriksa data-data sistem sesuai dan kemudian data-data tersebut akan diproses menjadi sebuah laporan dari masing-masing data.sedangkan admin 2 hanya dapat login dan melihat perekapan bulanan data barang sparepart yang sudah di kerjakan oleh admin 1.

Activity Diagram Berikut ini adalah gambar activity diagram untuk sistem Perancangan Aplikasi Sistem Inventoris Berbasis Android (Studi Kasus PT.ASM).

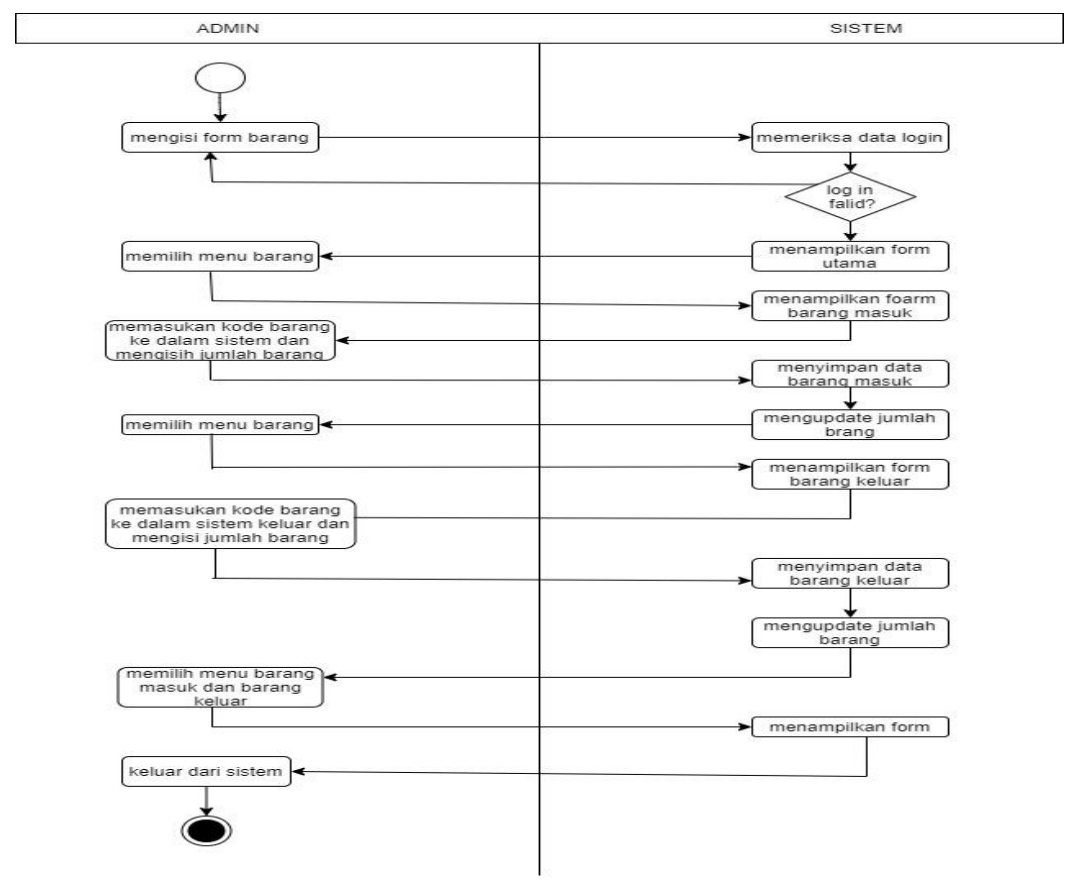

Gambar 2. Activity Diagram Sistem gudang 


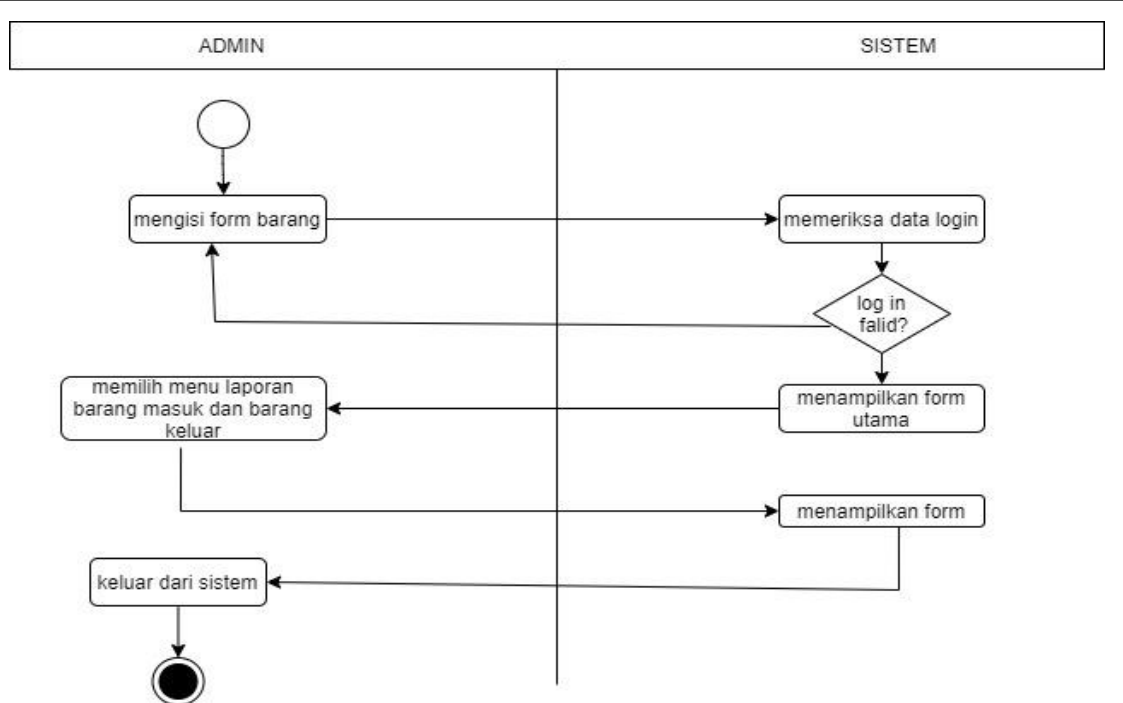

Gambar 3. Activity Diagram Sistem bengkel

Sequence Diagram adalah suatu diagram yang menggambarkan interaksi objek dan mengindikasikan (memberi petunjuk atau tanda) komunikasi diantara objek-objek tersebut, Sequence diagram digunakan untuk menggambarkan perilaku pada sebuah skenario dan mendeskripsikan bagaimana entitas dam sistem berinteraksi, termasuk pesan yang digunakan saat interaksi. Semua pesan dideskripsikan dalam urutan pada eksekusi[7]. Sequence diagram berhubungan erat dengan Use Case Diagram

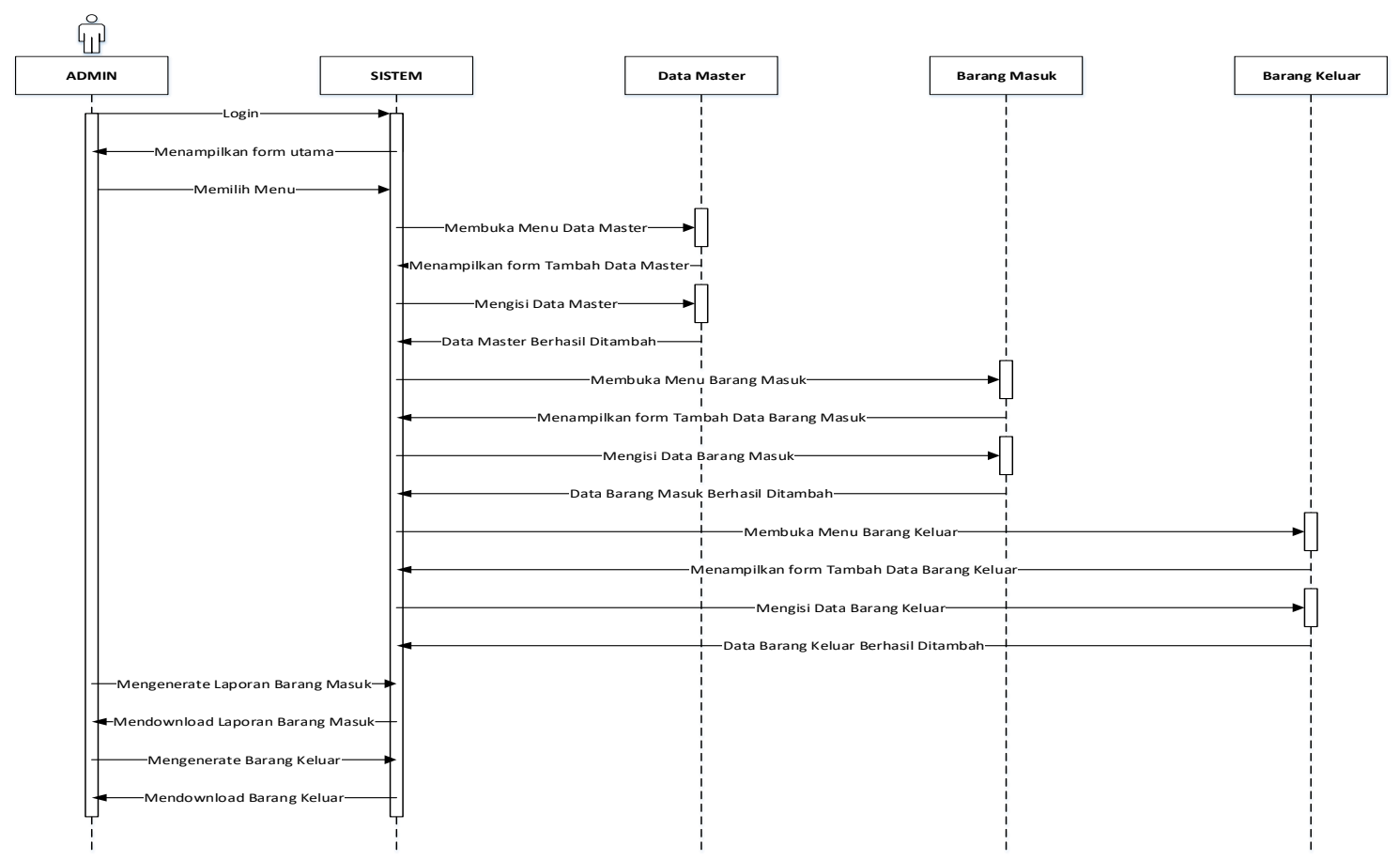

Gambar 4. Sequence Diagram Sistem

Class diagram adalah diagram yang menunjukan class-class yang ada dari sebuah sistem dan hubungannya secara logika[8]. Class diagram menggambarkan struktur statis dari sebuah sistem. Karena itu class diagram merupakan tulang punggung atau kekuatan dasar dari hampir setiap metode berorientasi objek termasuk UML[9]. 


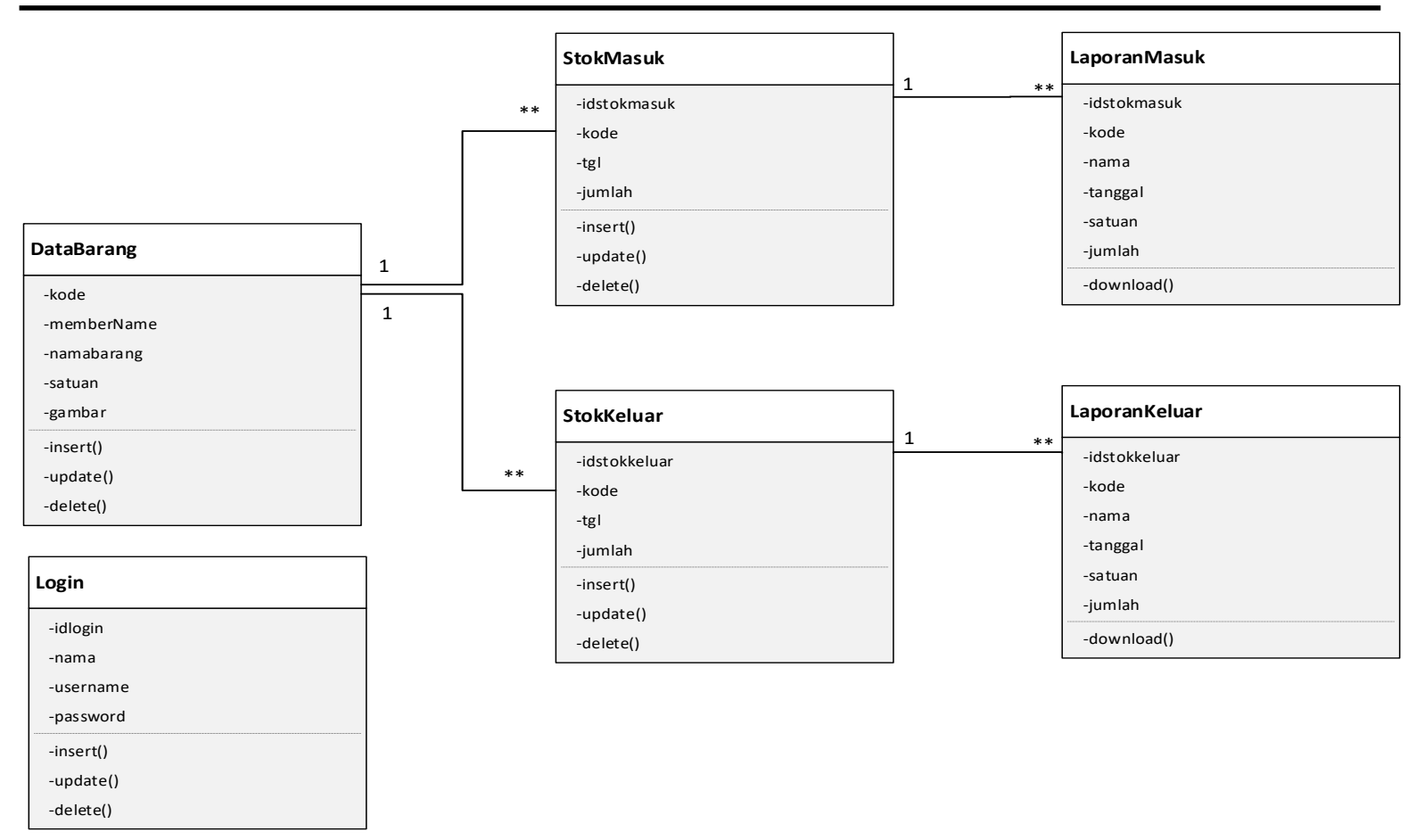

Gambar 5. Class Diagram Sistem

\section{Hasil dan Pembahasan}

Dalam pembuatan aplikasi Perancangan, Aplikasi Sistem Inventory Berbasis Android (Studi Kasus PT.(ASM) yang telah selesai dirancang, dibutuhkan perangkat keras (hardware), perangkat lunak (software) dan perangkat operator (brainware)[10]. Adapun hardware, software dan brainware yang dibutuhkan adalah sebagai berikut:

\section{Hardware (Perangkat Keras)}

Spesifikasi perangkat keras yang digunakan untuk membangun aplikasi ini sebagai berikut

a. Processor Intel Core i5

b. $\operatorname{Ram} 8 \mathrm{GHz}$

c. Harddisk $500 \mathrm{~Gb}$

d. Laptop Asus 14 Inch

e. Mouse

2. Perangkat Lunak (Software)

Spesifikasi perangkat keras yang digunakan untuk membangun aplikasi ini sebagai berikut

a. Sistem Operasi Windows 10 Professional Ultimate

b. IDE Android Studio

c. Notepad ++

\section{A. Tampilan Halaman Sistem Inventory PT.Asuransi Sinar Mas (ASM)}

Berikut adalah tampilan yang digunakan dalam aplikasi Perancangan Aplikasi Sistem Inventory Berbasis Android (Studi Kasus PT.ASM yang dibuat oleh penulis. Program ini sendiri dibuat dengan memasukkan semua kebutuhan standar yang ada didalam sistem manual yang biasa digunakan pada PT.

1. Halaman Login

Halaman ini adalah merupakan halaman yang akan tampil pertama kali setiap kali pengguna akan menggunakan aplikasi, disini pengguna wajib mengisikan username dan password yang telah tersimpan didalam database. 


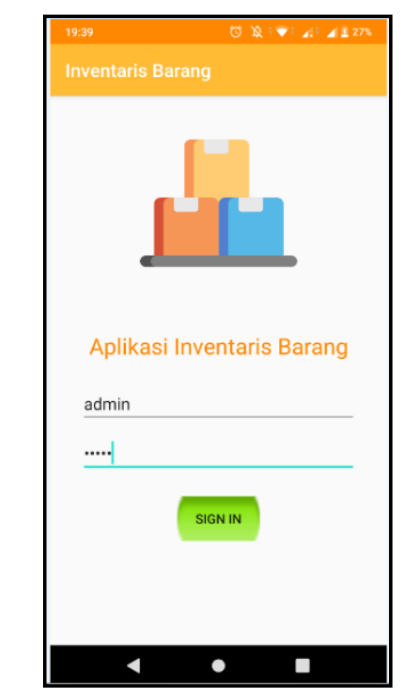

Gambar 6. Halaman Login

Berikut ini terdiri dari beberapa pilihan menu seperti home master barang,barang masuk barang keluar,laporan barang masuk dan laporan barang keluar user acound dan log out.

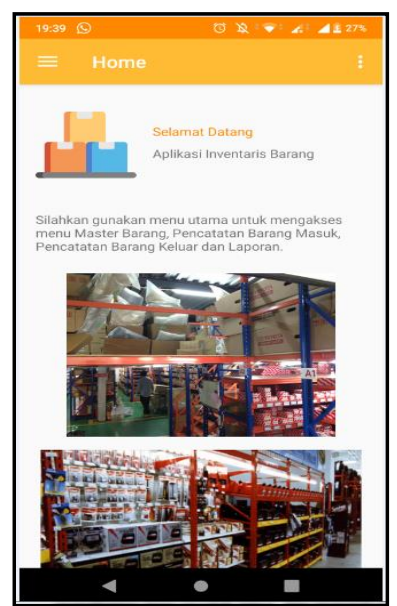

Gambar 7. Form Utama

2. File

Menu ini terdiri dari beberapa sub menu yang berfungsi untuk melakukan pengelolaan data inventory, seperti yang terlihat pada tampilan hasil berikut ini :

A. Form Data Master Barang

Bagian ini hanya bisa diakses oleh admin dikarenakan pada bagian ini admin dapat menambahkan item produk baru, menghapus item produk lama, dan mengubah isi informasi. 
B. Form Barang Masuk

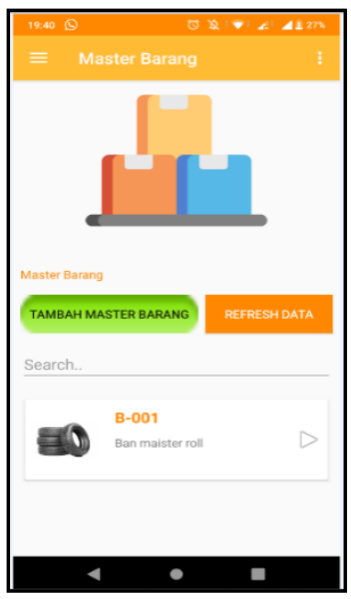

\section{Gambar 8. Halaman Data Master}

Pada bagian ini admin dan operator dapat memasukkan jumlah barang yang sebelumnya sudah terdaftar kedalam database sistem dan menyesuaikannya dengan jumlah barang yang ada.

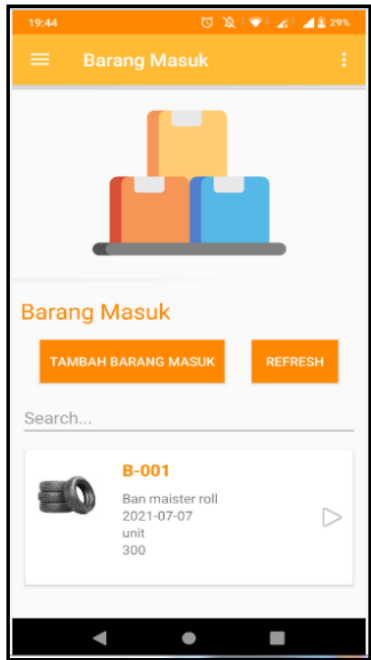

Gambar 9. Halaman Barang Masuk

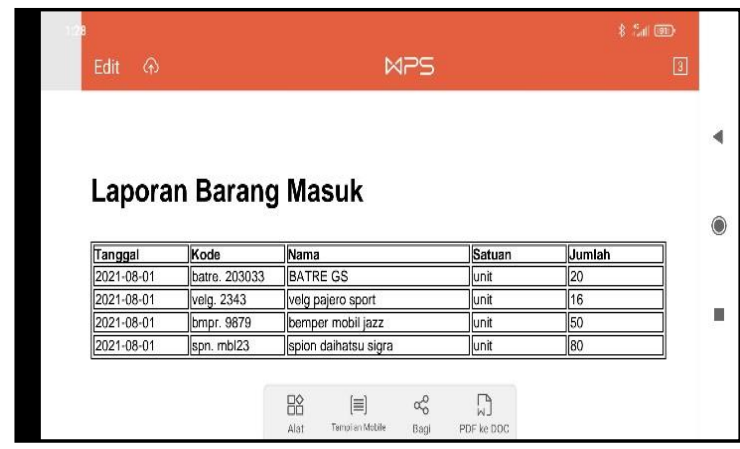

Gambar 10. Form Laporan Barang Masuk 


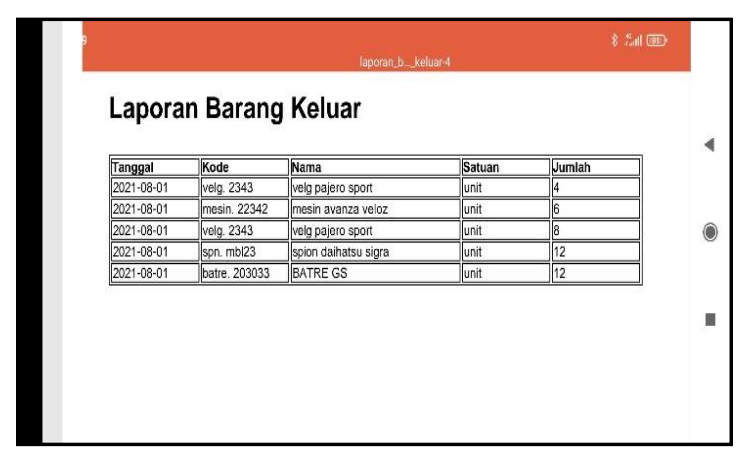

Gambar 11. Form Laporan Barang Keluar

\section{Kesimpulan}

Berdasarkan alur penelitian mulai dari analisa, perancangan, implementasi serta pengujian sistem informasi persediaan barang berbasis android yang telah dipaparkan sebelumnya, maka dapat ditarik kesimpulan sebagai berikut :

1. Dengan penggunaan database maka data transaksi dibagian inventory diharapkan dapat lebih terstruktur dan mudah didalam proses pengelolaan.

2. Dengan adanya sistem informasi persediaan barang berbasis android membuat data persediaan stok barang menjadi valid tanpa harus menunggu proses distribusi selesai dilakukan.

3. Sistem informasi ini menjadi lebih mudah digunakan karena sudah dalam bentuk aplikasi android, sehingga petugas gudang tidak perlu membawa laptop saat proses distribusi.

4. Stok persediaan barang dapat divalidasi oleh kepala gudang dimanapun dengan syarat terkoneksi jaringan internet sehingga jumlah stok persediaan barang digudang tervalidasi secara real time.

\section{Daftar Pustaka}

[1] Adrianto Dandy, 2017, Perancangan Aplikasi Berbasis Android Untuk Pemeriksaan Pengecatan Kapal Bangunan Baru, Jurnal Teknik Its Vol. 6, No. 1, (2017) Issn: 2337-3539 (2301-9271 Print)

[2] Alifa N.R dan Cahyo A.b, Analisis dan perancangan desain sistem informasi perpustakaan sekolah berdasarkan kebutuhan sistem, Vol. 14, No. 1, Juni 2018 SSN 1693-7740 (Print), ISSN 2477-0361 (Online).

[3] Hasanudin Maulana, 2018, Rancang Dan Bangun Sistem Informasi Inventori Barang Berbasis Web (Studi Kasus Pt. Nusantara Sejahtera Raya), Jurnal Ikra-Ith Informatika Vol 2 No 3 November 2018 Issn 25804316.

[4] Hendini Ade, 2016, Pemodelan Uml Sistem Informasi Monitoring Penjualan Dan Stok Barang (Studi Kasus: Distro Zhezha Pontianak), Jurnal Khatulistiwa Informatika, Vol. Iv, No. 2 Desember 2016.

[5] Hendini Ade, pemodelan Uml sistem informasi monitoring penjualan dan stok barang (studi kasus: Ddistro azezha pontianak), Vol. 4, No. 2 Desember 2016.

[6] Hidayat Rohmat, Dkk, Pembangunan Sistem Informasi Inventory Management Pada CV.Sumber Tani Cirebon, Yogyakarta, 10 Februari 2018 ISSN : 2302-3805.

[7] Nugraha Wahyu, Dkk, Penerapan Metode SDLC Water Fall Dalam Sistem Informasi Inventory Barang Berbasis Deskop, Vol 03 No.01, Juni 2018, Pontianak.

[8] Sonata Fifin, 2019, Pemanfaatan Uml (Unified Modeling Language) Dalam Perancangan Sistem Informasi E-Commerce Jenis Customer-To-Customer, Issn 2579-5899 (Online) Vol. 8 No. 1/Juni 2019 Issn 2303-1700 (Print) Doi: 10.31504/Komunika.V8i1.183222.

[9] Syafarina G.A , 2016, Perancangan Aplikasi Inventory Barang Materials Dan Product, "Technologia" Vol 7, No.1, Januari - Maret 2016.

[10] Utami N.F, 2018, Sistem Informasi Inventori Barang PT. Tissan Nugraha Globalindo Berbasis Web, Program Studi Informatika Fakultas Komunikasi Dan Informatika Universitas Muhammadiyah Surakarta 2018.

[11] D. I. Saragih and P. M. Hasugian, "Enkripsi Database Sekolah SMK Pembangunan Dengan Algoritma IDEA,” J. Nas. Komputasi dan Teknol. Inf., vol. 4, no. 1, pp. 50-56, 2021. 